\title{
Potensi Rumput Laut Dalam Menghambat Pertumbuhan Jamur Aspergillus flavus
}

\author{
KETUT SRIE MARHAENI JULYASIH*) DAN ARIKA PURNAWATI \\ Program Studi Agroteknologi Fakultas Pertanian UPN Veteran Jawa Timur \\ Jl. Raya Rungkut Madya Gunung Anyar, Surabaya 60293, Jawa Timur \\ ${ }^{*}$ E-mail: smjulyasih@gmail.com
}

\begin{abstract}
Potential of Seaweed in the Inhibition of Fungi Growth Aspergillus flavus. This use of synthetic chemicals as a controller of fungal growth in foodstuffs can have adverse effects on health, so it needs natural control ingredients that do not have an impact on human health. Various types of fungi such as Aspergillus flavus attack a lot of food items after harvest, these fungi can produce aflatoxin which is very toxic to consumers. Aflatoxin cannot be neutralized through cooking so efforts to avoid fungal contamination need to be done. One of the natural fungi controllers is by utilizing natural resources, including seaweed. Development of seaweed as an antifungal is an alternative that needs to be realized. For this reason, it is necessary to examine the potential inhibitory of seaweed A. flavus development. This study examined six types of seaweed like Gracilaria verrucosa, Euchema spinosum, Ulva lactuca, Ulva reticulata, Euchema edule, and Padina sp. The results showed that Padina sp. seaweed has a very strong potential inhibitory compared to other types of seaweed.
\end{abstract}

Keywords: seaweeds, fungi, aspergillus flavus

\section{PENDAHULUAN}

Rumput laut banyak mengandung senyawa kimia sebagai metabolit primer yang disebut hidrokoloid. Hidrokoloid telah dimanfaatkan untuk berbagai bahan industri seperti agar-agar, keraginan, alginat, dan sebagainya. Selain produk metabolit primer, produk metabolit sekundernya mulai banyak diteliti. Salah satu metabolit sekunder yang banyak dilakukan penelitian adalah senyawa bioaktif (bioactive substances) yang memiliki potensi untuk dikembangkan sebagai antimikroba seperti antibakteri, antijamur, antivirus, dan sebagainya (Eahamban and Marimutu., 2012).

Berbagai jenis jamur seperti Aspergillus flavussangat banyak menyerang bahan makanan pasca panen, jamur terebut dapat menghasilkan aflatoksin yang sangat beracun bagi konsumen. Aflatoksin tidak 
KETUT SRIE MARHAENI JULYASIH DAN ARIKA PURNAWATI. Potensi Rumput Laut Dalam...

dapat dinetralisir melaluii pemanasan sehingga upaya menghindari kontaminasi jamurnya perlu dilakukan (Siregar et al., 2012a).

Penggunaan bahan kimia sintetis sebagai pengendali pertumbuhan jamur pada bahan pangan dapat menimbulkan dampak yang merugikan bagi kesehatan, sehingga perlu bahan pengendali alami yang tidak menimbulkan dampak bagi kesehatan manusia.Salah satu pengendali jamur alami adalah dengan memanfaatkan sumber dari alam, diantaranya rumput laut.

Pemanfaatan rumput laut sebagai anti jamur merupakan salah satu alternatif pengendalian yang perlu dilakukan, oleh karena itu penelitian ini bertujuan untuk mengetahui potensi beberapa jenis rumput laut dalam menghambat perkembangan jamur Aspergillus flavus

\section{BAHAN DAN METODE}

Penelitian dilakukan di laboratorium Kesehatan Tanaman Fakultas Pertanian UPN "Veteran" Jawa Timur. Pengambilan sampel rumput laut di lakukan di pantai Sanur Bali. Tahapan pelaksanaan penelitian sebagai berikut :

\section{Pengambilan sampel dan Persiapan}

\section{Ekstrak Rumput Laut}

Rumput laut yang telah kering dihancurkan dengan alat blender, selanjutnya dilakukan proses maserasi selama 24 jam dalam pelarut ethanol $96 \%$, kemudian disaring dengan menggunakan kertas saring Whatman. Ekstrak yang diperoleh dilakukan proses pemisahan antara ethanol dengan rumput laut menggunakan alat vakum evaporator pada suhu $49-50^{\circ} \mathrm{C}$ sampai semua pelarut menguap, sehingga menghasilkan ekstrak kasar (crude extract). Ekstrak kasar rumput laut selanjutnya siap diuji potensinya sebagai anti jamur dan anti bakteri.

\section{Persiapan Inokulum Jamur A. flavus}

Menyiapkan biji jagung dengan gejala serangan A. flavus disterilkan dengan merendam dalam alkohol $70 \%$ selama 1 menit. Setelah dibilas dengan aquades steril, biji tersebut ditanam pada media PDA di dalam Petridish. Jamur yang tumbuh diamati menggunakan mikroskop dan diidentifikasi dengan mencocokkan struktur morfologi dengan buku Illustrated Genera of Imperfect Fungi. Jamur uji yang diperoleh disubkultur untuk mendapatkan biakan murni. 


\section{Uji Ekstrak Rumput Terhadap A. flavus}

Pengujian potensi ekstrak kasar (crude extract) sebagai antijamur dilakukan dengan menentukan daya hambat ekstrak dengan mengukur terbentuknya zona bening disekitar sumur ekstrak. Sebanyak $20 \mathrm{ml}$ PDA yang masih cair dituang ke dalam cawan petri. Setelah media padat, kemudian ekstrak rumput laut dimasukkan kedalam media dengan membuat lubang dengan alat corkborer $\varnothing 5 \mathrm{~mm}$ dengan konsentrasi 50 $\mathrm{mg} / \mathrm{ml}$. Disisi lain dibuat lubang dengan cork borer, dan selanjutnya lubang sumur diisi suspensi spora jamur uji sebanyak $40 \mu 1$.
Biakan diinkubasi selama $3 \times 24$ jam dan diameter zona bening yang terbentuk diukur. Kategori hambatan ditentukan mengikuti kategori Davis Stout (Hutasoit et al., 2013). Zona hambat $\leq 5 \mathrm{~mm}$, daya hambat lemah, 610mm kategori sedang, 11-20 mm sedang, > 20mm kategori sangat kuat.

\section{HASIL DAN PEMBAHASAN}

Hasil penelitian penghambatan ekstrak rumput laut terhadap jamur A.flavus diperoleh hasil seperti disajikan pada Gambar 1.

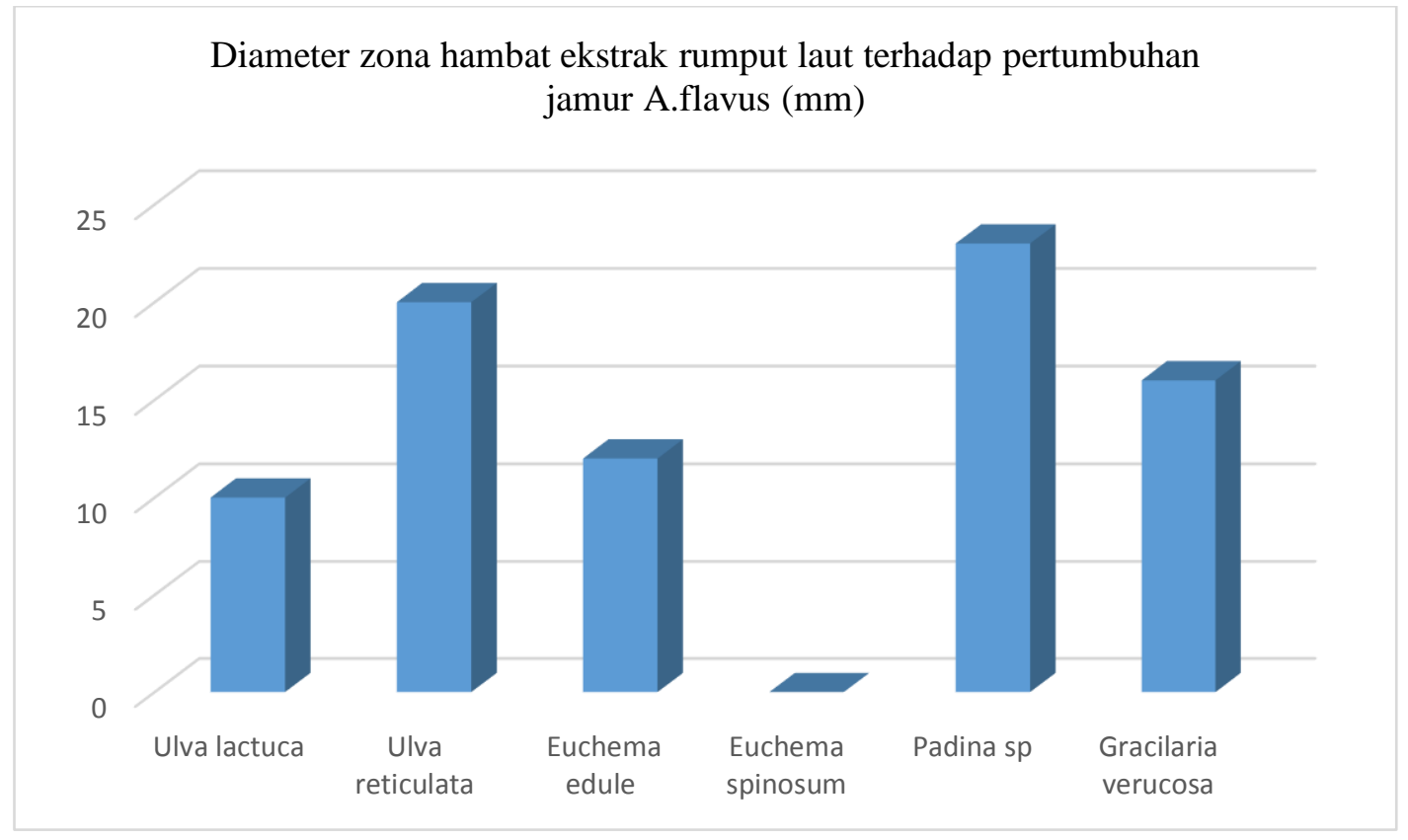

Gambar 1. Diameter zona hambat ekstrak rumput laut terhadap jamur A.flavus

Keterangan : Zona hambat $\leq 5 \mathrm{~mm}$, daya hambat lemah, 6-10mm kategori sedang, 11-20 mm kuat, >20mm kategori sangat kuat (Hutasoit et al., 2013) 


\section{KETUT SRIE MARHAENI JULYASIH DAN ARIKA PURNAWATI. Potensi Rumput Laut Dalam...}

Uji potensi beberapa jenis rumput laut dalam menghambat pertumbuhan jamur A.flavus diperoleh hasil bahwa jenis yang berpotensi kuat dalam menghambat pertumbuhan jamur A.flavus yaitu rumput laut Euchema edule, Gracilaria verucosa, Ulvare ticulata, Sedangkan rumput laut yang berpotensi sangat kuat menghambat perkembangan jamur A. Flavus adalah jenis Padina sp. dari kelompok Alga coklat (Phaeophyta) dengan diameter zona hambat $23 \mathrm{~mm}$. Euchema spinosum mempunyai diameter zona hambat $0 \mathrm{~mm}$, termasuk kategori lemah.

Potensi yang paling kuat dalam penghambatan jamur A.flavus kemungkinan karena kandungan senyawa fenolik, terpenoid, alkaloid, steroid, dan flavonoid pada rumput laut Padina sp (Cox et al., 2010).

Uji identifikasi fitokimia digunakan untuk mengetahui kandungan kimia dalam suatu bahan secara kualitatif. Rumput laut Padina sp diperoleh hasil mempunyai kemampuan menghambat sangat kuat. Keefektifan penghambatan merupakan suatu kriteria pemilihan senyawa anti mikroba untuk pestisida nabati. Kerusakan yang ditimbulkan komponen antimikroba dapat bersifat fungisidal (membunuh jamur) dan fungistatik (menghentikan sementara pertumbuhan jamur). Suatu komponen akan bersifat fungisidal atau fungistatik tergantung pada sifat senyawa aktif, konsentrasi, dan media yang digunakan (Chalyyn et al., 2017).

Alga cokelat mengandung bahan alginat dan iodin yang bermanfaat bagi industri makanan, farmasi, kosmetik dan tekstil dan memiliki kandungan $\mathrm{Mg}, \mathrm{Na}, \mathrm{Fe}$, tanin, iodin dan fenol yang berpotensi sebagai bahan anti mikroba (Bachtiar et al., 2012).

Alga hijau, merah, ataupun coklat merupakan sumber potensial senyawa bioaktif yang sangat bermanfaat bagi pengembangan 1) industri farmasi seperti antibakteri, anti tumor, anti kanker, dan 2) industri agrokimia terutama untuk anti feedant, fungisida, dan herbisida (Siregar et.al., 2012b). Penelitian yang dilakukan oleh Tosiyah et.al (2016) pada rumput laut Caulerpa sp. menunjukkan aktivitas yang sangat kuat dalam menghambat jamur Aspergillus flavus. Keefektifan penghambatan merupakan suatu kriteria pemilihan senyawa anti mikroba untuk pestisida nabati.

\section{SIMPULAN}

Jenis rumput laut yang paling kuat dalam menghambat pertumbuhan jamur 
A.flavus adalah yaitu kelompok alga coklat dari jenis Padina sp. dengan diameter zona hambat $23 \mathrm{~mm}$, termasuk kategori sangat kuat. Jenis rumput laut E.spinosum mempunyai daya hambat yang paling lemah dalam menghambat pertumbuhan jamur A.flavus yaitu kelompok alga merah dengan diameter zona hambat $0 \mathrm{~mm}$.

\section{UCAPAN TERIMA KASIH}

Ucapan terimakasih disampaikan kepada Direktorat Jenderal Penguatan Riset dan Pengembangan melalui Direktorat Riset dan Pengabdian Masyarakat Kementerian Riset Teknologi dan PendidikanTinggi yang telah mendanai Penelitian Dasar Unggulan Perguruan Tinggi selama dua tahun, yaitu tahun 2017 dan 2018.

\section{DAFTAR PUSTAKA}

Bachtiar, S.Y., W. Tjahyaningsih., dan N.Sianita. 2012. Effect of Algae Brown (Sargassumsp.) Ekstract Againts Bacterial Growth of Escherichiacoli. Journal of Marine and Coastal Sciences ,1(1):53-60.

Chalyyn, Pakidi dan Hidayat. 2017. Potensi dan Pemanfaatan Bahan aktif Alga Coklatsargassum sp. Octopus Jurnal Ilmu Perikanan. Vol 6 No 1

Cox,S.,Ghanam,N., Gupta,S. 2010. An assesment of the Antioxidant and Antimicrobial activity of six species of
Edible Irish Seaweeds. International Food Research Journal 17: 205-220

Eahamban,K and J. Marimuthu. 2012. Preliminary Phytochemicals, UV-VIS HPLC and Antibacterial Studies on Gracilaria corticata. Asian Pasific Journal of Tropical Biomedicine. 55405574

Hutasoit, H., I.K.Suada.,I.G.K Susrama. 2013. Uji Aktivitas Antijamur Ekstrak Beberapa Jenis Biota Laut terhadap Aspergillus flavus LINK dan Penicilliumsp.LINK. E-Jurnal Agroekoteknologi Tropika ISSN:23016515 Vol. 2,No.1.

Maryam, R. 2006. Pengendalian terpadu kontaminasi mitotoksin. Balai Penelitian Veteriner. 16 (1):21-30. http://bbalitvet.litbang.pertanian.go.id. Akses 04 November 2015.

Siregar, A.F., S. Agus dan P. Delianis. 2012a. Potensi Antijamur dan Antibakteri Ekstrak Rumput Laut terhadap Jamur A. flavus dan Bakteri Pseudomonas aeruginosa. http://ejournal-

s1.undip.ac.id/index.php/jmr. Akses 11 April 2016.

Siregar, A.F., S. Agus dan P. Delianis. 2012b. Potensi Anti Bakteri Ekstrak Rumput Laut Terhadap Bakteri Penyakit Kulit Pseudomonas aeruginosa, Staphylococcus epidermides, dan Micrococcus luteus. Journal of Marine Research . Volume 1 No 2. Hal 152-160

Tosiyah, K.S.M Julyasih, dan A.Purnawati. 2016. Kemampuan Ekstrak Rumput Laut Bulung Boni (Caulerpa sp.) dalam Menghambat Pertumbuhan Aspergillus Flavus pada Biji Jagung. Jurnal Plumula. Volume 5 No 2. Hal 168-178 